New Zealand journal of industrial relations, 1988, 13, 121-142

\title{
The state, wage-fixing and labour market reform: some international perspectives
}

\author{
Jonathan Boston*
}

This article explores three main issues. First, it examines the changes which have occurred in the nature and scope of state intervention in pay fixing within the $O E C D$ during the past two decades. Second, it outlines the strategies which have been adopted recently by many western governments to enhance wage flexibility and improve the operation of labour markets. Third, it critically assesses the merits of the CalmforsDriffill thesis concerning the relationship between wage bargaining systems and macroeconomic performance. It is argued that there are good theoretical reasons as well as some strong empirical evidence to support the Calmfors-Driffill thesis, but that bargaining structures are only one of a multitude of factors which influence economic outcomes.

\section{Introduction}

Public policy with respect to labour relations and wage-fixing in New Zealand has undergone something of a minor revolution in recent years. Attempts at controlling nominal and real wage growth by means of statutory incomes policies - which were a prominent feature of macroeconomic policy in the 1970s and early 1980 s - have been abandoned. Instead, the Labour Government has relied primarily on monetary policy, and to a lesser extent fiscal policy, in its efforts to reduce the rate of inflation. At the same time, it has introduced a series of supply-side measures designed to enhance the flexibility of the labour market and thereby improve the overall performance of the economy. There have been major reforms to industrial relations legislation in both the public and private sectors. Job training programmes have been redesigned and expanded. The tax system has been overhauled with the objective, amongst other things, of increasing work incentives. And various measures have been introduced to enhance the occupational and geographical mobility of labour.

The purpose of this article is to explore how these developments relate to the experience of other OECD countries during the past decade or so. Three topics will be given particular attention. First, what changes are evident within the OECD with respect to the pattern of state intervention in the wage-fixing process? Has there been a general abandonment of incomes policies, or is it rather that the nature and scope of incomes policies have changed? Second, how widespread is the quest for labour market reform, especially attempts at increasing wage flexibility? And third, what does the evidence 
suggest about the relative merits of different wage-fixing arrangements? In particular, are Calmfors and Driffill (1987) correct in their judgement that the best wage-fixing systems, at least from a macroeconomic perspective, are those with either highly centralised or highly decentralised bargaining arrangements? And if they are, what implications does this have for the future direction of New Zealand labour relations?

\section{State intervention in the process of wage-fixing}

It is sometimes suggested that whereas the 1970 s marked the heyday of incomes policies and interventionism, the 1980s has been the decade of monetarism. For example, it is argued that in most OECD countries firm, non-accommodating monetary policies have replaced wage and price controls as the chief weapon for tackling inflation. Further, it is pointed out that many governments, particularly of a conservative or New Right disposition, have abandoned attempts at winning trade union support for wage restraint and have instead sought to reduce union power, both in the labour market and in the political domain generally. It is also suggested that corporatist arrangements (Crouch 1977; Schmitter and Lehmbruch, 1979), which have long been a central feature of Scandinavian and Austrian labour relations, have begun to disintegrate (Lash, 1985). How valid is this interpretation?

It is certainly true that incomes policies were widely employed during the 1970 s as an instrument for curbing inflation and unemployment. Throughout this period governments of varying political persuasions resorted to some form of direct intervention in the process of wage and price determination in the interests of economic stability (Flanagan, Soskice and Ulman, 1983; Marks, 1986; Van Ginneken, 1987). Statutory wage controls were imposed in Belgium (1976), Britain (1973-74), Canada (1975-78), Denmark (1976-80), the Netherlands (1976), New Zealand (1971-77), Norway (1978-79), Portugal (1974-75), and the United States (1971-73), to mention but a few examples. Voluntary wage deals of a bilateral or tripartite kind were negotiated in numerous OECD countries including Austria, Belgium, Britain, Denmark, Finland, Ireland, Italy, Japan, Norway and Spain. Various forms of wage indexation were experimented with in Australia, Denmark, Greece, Israel, Italy, and Spain. Moreover, most governments resorted at some stage during the 1970 s to price controls of one form or another, and attempted to reduce wage settlements by means of indicative guidelines, moral suasion or political pressure.

However, the suggestion that the 1980s have brought an abrupt and radical change in macroeconomic policy with a general abandonment of incomes policies within the OECD is not sustained by the evidence. For example, during the past eight years or so incomes policies of either a statutory or negotiated variety have been used in no fewer that 14 OECD countries - Australia, Austria, Belgium, Denmark, France, Greece, Iceland, Ireland, Italy, the Netherlands, New Zealand, Norway, Spain and Sweden. Further, most governments have made determined efforts to restrain wage settlements in the public sector, partly for fiscal reasons and partly so as to exert an indirect influence on private sector settlements. At the same time, two important changes in public policy are evident.

First, there has been a general shift in emphasis in macroeconomic management during the past decade. Whereas in the 1970 s incomes policies bore much of the brunt of controlling inflation, with monetary and fiscal policies playing a secondary role, during the 1980 s the pattern has been reversed. Now most governments, be they conservative, liberal or social democratic, are relying primarily on firm monetary and fiscal policies to keep inflation in check. Incomes policies have thus become essentially supplementary instruments of macroeconomic management. Moreover, with the problems of high inflation after the first and second oil shocks having been largely overcome in most OECD countries (with a few notable exceptions) the role of incomes policies has changed somewhat. During the 1970 s and early 1980 s, incomes policies were generally used on a short-term basis as a means of assisting the process of disinflation by breaking through 
wage-price and wage-wage ratchets and curbing inflationary expectations. In this context they were seen, at least in part, as an instrument for reducing the transition costs - in terms of lower output and employment - normally associated with a disinflationary macroeconomic strategy (Boston, 1984, pp.44-46). In more recent years incomes policies have been used increasingly as an instrument for restraining the growth of real wages and thereby facilitating faster employment growth. Such a strategy has been central, for example, to the policies adopted in Australia, Denmark, Greece, the Netherlands and Norway during the past few years.

Second, some conservative governments, most notably the Thatcher and Reagan administrations, have firmly rejected any attempt to influence the level or pattern of wage settlements in the private sector by direct means. This is because they believe that such a strategy is unnecessary as well as being both ineffective and inefficient. It would be ineffective in that it is likely merely to suppress inflationary pressures for a temporary period. Once the controls have been lifted there would be a rebound effect with nominal wage growth accelerating and wage levels returning to what they would have been in the absence of the incomes policy. Such intervention would also be inefficient, or so it is claimed, because it would prevent relative wages adjusting in response to the forces of supply and demand. Whether such arguments are valid will not be explored here. Suffice it to say that the empirical evidence is conflicting and that, because of a variety of economic, political and industrial relations considerations, incomes policies are difficult to implement successfully on a long-term basis. As a result, most state interventions in the wage-fixing process tend to be of a short-term and rather ad hoc nature. In this respect the 1980 s have been little different from the preceding decade.

Of course, any attempt to classify or categorise such interventions or to group countries according to the type of incomes policy in operation (or lack of it) is beset with difficulties. To start with, incomes policies vary greatly in their nature, scope and impact. Depending on the liberality of the definition adopted they might include anything from a simple, state-sanctioned but unenforceable wage guideline to a complex set of institutional arrangements and policy tradeoffs of either the Austrian or Australian variety. To compound problems, government policies are constantly changing. Hence, while it might be justified to locate a particular country in a certain class or category at a given moment, such a classification may quickly lose its validity. Despite these difficulties, it can be argued that, in very broad terms, four main groupings can be discerned during the $1980 \mathrm{~s}$.

\section{Countries with no formal incomes policy}

First, there are those countries, such as Britain, Canada, Switzerland and the United States, where wage bargaining is largely decentralised and where governments since the late 1970s have eschewed any form of intervention in the system of wage determination, at least with respect to the private sector. Thus, they have avoided wage controls, bilateral or tripartite deals, wage-tax tradeoffs and compulsory arbitration, and have relied almost exclusively on monetary and fiscal policies to restrain nominal and real-wage growth.

\section{Countries with bilateral or tripartite wage-fixing forums}

The next category which can be identified are those countries in which there are regular (usually annual) consultations either of a bilateral (employers and unions, or unions and the government) or tripartite nature (unions, employers and the government) to discuss the overall economic situation and the general level of wage settlements that would be appropriate in the light of the government's macroeconomic strategy and policy objectives. Such consultations may or may not produce an agreement on a wage guideline for the forthcoming negotiating round. 
Needless to say, there is considerable variation within this category. In Sweden the consultations have tended to be of a bilateral (employers and unions) rather than a tripartite nature, though formal government involvement has increased during the past decade as the country's economic problems have intensified (Lash, 1985). Interestingly, in 1984 the Swedish employers' organization SAF broke the 50 -year old tradition of highly centralised wage bargaining and demanded that negotiations occur only at the company level. Centralised bargaining has subsequently been resumed. In Japan there is a National Economic Conference (Sanrokan) each year just prior to the commencement of the annual wage round (what is often termed the "Spring Offensive") (Van Ginneken, 1987, p.383). This Conference was initiated in the wake of the first oil shock in 1974 and has since become an important feature of the bargaining process. A similar arrangement, known as "concerted action", existed in West Germany for many years but fell into disuse during the late 1970s (Hudson, 1980). Since then the peak organizations of labour and capital have continued to maintain an on-going dialogue with ministers and government officials, but formal consultative arrangements have not been reinstated. An important feature of the West German wage-fixing system is the emphasis put on coordinated action by employers and unions and the general synchronization of wage settlements (Crouch, 1985, pp.127137).

Without doubt the most sophisticated and enduring forums for multi-lateral interaction and policy coordination continue to be those in Norway and Austria. In Norway the main body concerned with inter-sectoral consultation on macroeconomic issues is known as the Contact Committee (Addison, 1979, pp.78-86; Flanagan, Soskice and Ulman, 1983, p.171-173). This was formed in 1962 following a brief but rapid acceleration in the rate of inflation, and includes ministers, union and employer leaders, and representatives of the agricultural and fishing industries. Since 1965 the Contact Committee has been serviced by an expert group of economists, initially known as the Aukrust Committee - after its first chairperson - but subsequently referred to as the Technical Reporting Committee on the Income Settlement (TRC). The role of the TRC is to provide a detailed analysis of the economic situation and expected developments, and in the light of this to indicate the likely impact of alternative wage paths or settlement levels. This analysis is then considered by the Contact Committee in preparation for the commencement of the forthcoming wage round. At this juncture a range of strategies may be adopted. For example, all the parties may agree to negotiate what have been referred to as "combined settlements". These involve a central agreement on contractual wage increases (usually with some allowance for wage drift), together with changes in various government policies, such as tax policy, industry assistance and social policy (Schwerin, 1980). Alternatively, the peak organizations of labour (LO) and capital (NAF) may undertake bilateral negotiations on contractual wage increases against the background of government guidelines presented to the Contact Committee. If the parties fail to reach an agreement, a mediator is brought in and given a short time to effect some accommodation. If this also fails then the parties will generally take industrial action. From time to time the government has intervened at this point and imposed compulsory arbitration. On rare occasions it has also introduced temporary wage and price controls.

This system of centralised negotiations dealing with wages and other economic and social issues has continued now for more than a quarter of a century. The pattern in recent years exemplifies the variation in possible policy outcomes outlined above. In 1985 the LO and NAF agreed that there would be no general wage adjustment, except for certain low-wage sectors. This meant that bargaining occurred primarily at a decentralised level. In 1986 the parties had considerable difficulty reaching an agreement at the central level. Eventually, after a major strike in the public sector and a lockout in the private sector a deal was worked out whereby wage increases of $2-3 \%$ were agreed for the private sector with somewhat higher increases for public sector employees. In exchange for an acceptance by the unions of a relatively small wage rise, the employers agreed to a reduction in working hours from 40 hours to 37.5 hours from the beginning of 1987 . 
Given the impact on labour costs as a result of this move, the parties decided that there would be no general wage increases during 1987-88. In return for this the government promised to reform the tax system, partly to make it more equitable and partly to preserve real disposable incomes.

It remains to be seen how much longer the current bargaining arrangements will survive in Norway. The system is undoubtedly under pressure. To start with, the LO's dominant position as the principal representative of organised labour is gradually being undermined as a result of the formation of new, independent unions. These unions tend to be unsympathetic to the LO's traditionally moderate stance and are less committed to the pursuit of consensual incomes policies. If this trend continues, the LO may soon be unable to command the support of rank-and-file workers and the system of centralised negotiations and combined settlements may be jeopardised. Quite apart from this, there has been a significant change in the relative importance of centralised and decentralised bargaining during the past two decades. In the 1970 s, roughly two-thirds of the aggregate movement in wage rates in the private sector was determined through contractual agreements reached between the LO and the NAF, the remaining third arising from wage drift at the plant or enterprise level. By the mid-1980s the proportions had been virtually reversed (OECD, 1985, p.20). Effectively, therefore, power is shifting from the national and industry level to the enterprise level.

The other feature of Norwegian incomes policy which is worth noting is the gradual move away from its earlier emphasis on a solidaristic or egalitarian ethos. In accordance with the $85 \%$ rule which was in force between 1980 and 1984, the lowest paid employees in each industry (or branch) had to be paid at least $85 \%$ of the average industrial wage. The aim of this policy was to protect the position of low-paid workers and reduce skill differentials. But, as many expected, this approach was resisted by skilled employees and tended to exacerbate the degree of wage drift. In the mid-1980s, therefore, the rule was modified to facilitate greater wage flexibility. As it currently stands, the rule requires that average wage rates in each industry must be at least $85 \%$ of the average industrial wage.

In Austria, collabouration between the government, unions and employers over macroeconomic issues, social policy and wages policy began shortly after the Second World War. Following the surge in the rate of inflation in the mid-1950s, which heightened fears of a return to the hyperinflation and political instability which had characterized the $1920 \mathrm{~s}$, the union movement sought the establishment of a consultative forum to restrain price rises and ensure that real wages were protected. This led to the creation of a Parity Commission for Wages and Prices in 1957. Initially it was intended to be a temporary body, but the arrangement proved so successful that the Parity Commission has remained in existence for more than three decades (Dunkley, 1984; Flanagan, Soskice and Ulman, 1983, pp.40-82; Marin, 1985; Mire, 1981; and Prager, 1981).

The Commission is a voluntary, multi-lateral organization with representatives from the government, the Chambers of Commerce, Agriculture and Labour, and the trade union movement. It is chaired by the Federal Chancellor and meets monthly. A wide range of matters of mutual interest are discussed, including economic, social and industrial relations issues. Most of the detailed work of the Commission is undertaken by its three subcommittees: the Sub-Committee on Prices, the Sub-Committee on Wages, and the Economic and Social Advisory Board. Of these the Sub-Committee on Wages is the most important. It meets fortnightly and its decisions must be unanimous. It does not, however, have any legal powers and must rely on moral suasion to achieve its objectives.

The Sub-Committee has two important roles in the wage-fixing process. First, it provides a forum within which the peak organisations of labour and capital can evaluate the economic situation and can seek to reach a consensus on the overall level of wage growth that is appropriate and sustainable (i.e. given certain objectives with respect to inflation, employment and international competitiveness). Second, any union wishing to commence bargaining over wages and conditions cannot proceed until it has obtained the 
approval of both the central union organisation (OGB) and the Sub-Committee. The latter body has six weeks to arrive at a decision. If it fails to do so, the matter must be put before the Parity Commission, which also has six weeks to reach an agreement. If at the end of this period the Commission remains undecided, the union can commence its negotiations with employers. Through these procedures the central organisations of labour and capital are able to influence both the timing and to some extent the size of pay increases.

Austrian unions rarely ignore the Commission's informal guidelines and its directives with regard to the commencement of wage negotiations. Nevertheless, as in Norway, the peak organisations have difficulty controlling the level of wage drift at the enterprise level. This appears to be the achilles' heel of centralised wage-fixing systems and corporatist incomes policies. In the Austrian case, however, it has not as yet threatened the integrity of the current institutional arrangements. One reason for this lies in the substantial control which the national unions are able to exercise over the activities of the works councils within individual enterprises. A more serious problem in the future, therefore, may arise from the growing dissatisfaction at the grass roots level with the highly centralised nature of decision making in Austrian unions (Duda and Todtling, 1986, pp.263-265). How the union leadership responds to such pressures, in particular the quest for greater democratic control, remains to be seen.

\section{Countries with incomes policies fashioned by independent arbitral bodies.}

A third category of countries are those with incomes policies in which a central role is played by an independent arbitral body. The best example of such a system at present is Australia, though New Zealand also fell into this category during the 1950s and 1960s. The Australian system of conciliation and arbitration, which was modeled on the pioneering reforms in New Zealand in the late 19th century, came into being in 1904 and has continued, with various modifications, ever since. The central coordinating and decision-making body is the Australian Conciliation and Arbitration Commission (ACAC). In the past few decades, this has played an increasingly important role in the wage-fixing process and as a vehicle for achieving the government's stabilisation objectives. For example, between 1975 and 1981 the ACAC was responsible for implementing a highly centralised wage indexation policy (Plowman, 1982). This strategy began to disintegrate in the early 1980 s and for a brief period the country returned to a form of decentralised pay bargaining. The result, in short, was a significant acceleration in the rate of wage inflation. This in turn prompted the Fraser Government to impose a wage freeze in December 1982.

Since March 1983 wage-fixing in Australia has been dominated by the Labour Government's Wage Accord with the Australian Council of Trade Unions (ACTU). The Accord, which was devised while the Labour Party was in Opposition, has two main components: a commitment to centralised wage-fixing based on the ACAC and in accordance with which wages are linked primarily to price increases and changes in productivity; and a consultative approach to economic management in which the unions, employers and other interest groups have the opportunity to exercise a significant influence on important matters of public policy (Burch, 1985; Gerritsen, 1986; Mulvey, 1984; Stewart, 1985; Singleton, 1985). Despite widespread expectations that the Accord would quickly collapse and that centralised wage determination would be undermined by the activities of militant trade unions, the pay-fixing machinery put in place in mid-1983 has remained largely intact.

There have, of course, been some important changes to the policy framework during the past few years. Indeed, to date three separate phases of the policy can be identified. Under the principles agreed in mid-1983 - i.e. Mark I of the Accord - a system of wage 
indexation was introduced whereby the Arbitration Commission granted 6-monthly wage adjustments of a uniform percentage amount (OECD, 1984, pp.54-57). These were based on movements in the CPI during the preceding 6 months. In addition, the parties agreed to defer consideration of claims based on national productivity movements until 1985 , with work value claims being deferred until February 1984. In order to be eligible to receive national pay increases awarded by the Commission, each union was obliged to give an undertaking that it would not pursue extra claims outside the scope of the policy principles.

During the spring of 1985 the Labour Government reached an agreement with the ACTU on Mark II of the Accord (Petridis, 1986). The new set of principles was developed against the background of a substantial devaluation of the Australian dollar and a general desire to ensure that this did not trigger a renewed burst of inflation. There was also a widespread recognition that real wages would have to fall in the short run if the Government's objectives with respect to international competitiveness and employment growth were to be fulfilled. Given these considerations, it was agreed that, although the national wage case in September 1985 would be based on full indexation, this practice could not continue during 1986. Full indexation would be temporarily suspended. The net result was a formula whereby the Arbitration Commission would award a general wage increase in the early part of 1986 based on the CPI movement in the 6 months to the end of 1985 , minus 2 percent. In the event, the decision of the Commission was delayed until June 1986; the actual increase awarded was 2.3 percent. In addition to the agreement on discounting, the ACTU also accepted the need to delay further its quest for pay increases based on productivity gains. It did, however, secure an agreement from the Government that tax cuts would be implemented during 1986 to help preserve real disposable incomes.

During the latter part of 1986 there were growing pressures from both employers and trade unions, for some modification of the indexation principles to facilitate greater wage flexibility, and in particular to provide more scope for bargaining at a decentralised level (Petridis, 1987). For example, at the national wage case in November 1986 the ACTU called for the introduction of a two-tier wage system. Under this there would be two flat wage increases for all workers during 1987, together with decentralised bargaining up to some agreed amount. The employers also favoured a two-tier system, but argued that there should be only one general wage rise awarded during 1987 and that both this and any second-tier movements should be based on capacity-to-pay arguments, rather than on relativity or CPI considerations. In December 1986, the Arbitration Commission decided to terminate the centralised wage indexation regime and introduce a two-tiered system. However, it left the details of the new wage-fixing arrangements to be determined by an all-party conference in January 1987 . Eventually it was decided to that there would be a flat rate pay increase of $\$ 10$ in March 1987 with a further pay rise of up to 1.5 percent permitted in October 1987. On top of this, unions were free to bargain with their employers for wage increases of up to 4 percent.

4. Countries in which incomes policies continue to be employed for temporary periods

The last category are those OECD countries without permanent, centralised wage-fixing machinery of a bilateral, tripartite or arbitral kind but in which incomes policies of one form or another have been implemented during the 1980s. Such countries include Belgium, Denmark, Finland, France, Greece, Iceland, Ireland, Italy, the Netherlands and Spain (Van Ginneken, 1987). For example, statutory incomes policies were imposed in Denmark (1985-86), France (1982), Greece (1985-87) and Iceland (1983-84). There have also been comprehensive bilateral or tripartite agreements in Belgium (1986), Iceland (1986), Italy (1983-85), the Netherlands (1982) and Spain (1984). 
A prominent feature of the first half of the 1980s was the attempt of many OECD countries to modify, suspend, or terminate altogether the various systems of automatic wage indexation which had flourished in the 1970 s. For example, the wage indexation scheme in Denmark was suspended in 1982 for 3 years, and subsequently suspended until 1987 (OECD, 1986, p.14). Wage indexation was suspended in Belgium between 1982 and 1986 and in Luxembourg between 1982 and 1983 (Van Ginneken, 1987, p.395). Where full or partial indexation arrangements have remained in place, such as in France, Greece and Spain, there has been a general trend away from retrospective indexation in favour of ex ante indexation (i.e. wages are adjusted on the basis of expected price increases, and sometimes protected via catch-up clauses). This arrangement may be satisfactory during a period of falling inflation but is potentially very damaging economically if price inflation accelerates unexpectedly.

Where does New Zealand fit into this pattern? Clearly, the role of the state in the process of wage determination in this country, and the overall policy framework within which bargaining occurs, has changed significantly during the past few decades. Up until the 1960 s New Zealand would have been grouped with Australia in the category of countries with a formal incomes policy based on an independent arbitral body which conducted regular (i.e. annual or biennial) national wage hearings. From the early 1970s until the mid-1980s it moved into the category of countries with temporary, ad hoc state intervention or short-lived wage accords. Since late 1984, New Zealand has joined those countries with regular, centralised discussions on wages policy and related issues through the vehicle of the Tripartite Wage Conference (TWC). However, the TWC is a much less important consultative and coordinating body than its counterparts in Austria and Norway. It has no legal power or effective control over the bargaining behaviour of employers and unions. And in its three and a half years of operations it has not reached a single agreement on a wage guideline, though some attempts to do so were made in late 1984 and mid-1985. Moreover, there seems little prospect, given the current economic climate and dominance of market-liberal thinking, that its role will be greatly enhanced during the next few years. Nevertheless, the TWC could become an important vehicle for coordinating economic policies and facilitating union and employer input into government decision-making given a collective desire for this to occur.

In summary, it has been argued in this section that incomes policies of various kinds have remained important instruments of macroeconomic management during the $1980 \mathrm{~s}$ in a large number of OECD countries. Nevertheless, they are undoubtedly less fashionable than was the case during the 1970 s and most governments are today relying primarily on restrictive monetary and fiscal policies to control inflation and create the conditions for stable economic growth. The changes in macroeconomic policy since the late 1970s are obviously due to the influence of monetarist and supply-side theories (and the simultaneous demise of Keynesian economics), together with the difficulties of implementing incomes policies successfully. In particular, governments and employers have been dissatisfied with the general failure of unions to abide by the terms of negotiated policies, and the tendency for unions to demand substantial policy concessions in return for their cooperation on the wages front.

Whether there will be a greater reliance on incomes policies during the coming decade is hard to predict, but it is unlikely. Rather, governments will probably place an even greater emphasis on labour market reform and other supply-side measures with formal incomes policies being resorted to only sporadically to cope with short-term economic crises. As for the corporatist arrangements in Scandinavia and Austria, it seems likely that these will continue in the meantime, but if the general trend to decentralised bargaining gathers momentum they will doubtless be more difficult to sustain (Calmfors and Driffill, 1987; Lash, 1985; Marks, 1986). Of course, such predictions could be rendered utterly false if the world economy suffers a series of inflationary shocks of the kind experienced in the 1970 s or if there is a major increase in distributional dissent, 
labour militancy and bargaining intensity. In these circumstances incomes policies might again become politically attractive.

\section{Labour market reform and the quest for wage flexibility}

The depressed character of labour market conditions during the 1980s and the protracted period of high unemployment which has afflicted most OECD countries during the 1980s has led to a widespread concern with the question of labour market flexibility. In brief, it has been argued, certainly by economists of a neo-classical persuasion, that the high unemployment of the $1980 \mathrm{~s}$ is the product not of inadequate aggregate demand but of rigid industrial relations institutions, comprehensive employment security arrangements and inflexible wages. As evidence for this it is claimed that unemployment levels have been significantly lower in countries with apparently flexible labour markets, such as Japan, Switzerland and the United States, than in countries with arguably more inflexible labour markets, like Britain, Ireland, the Netherlands and Spain (Piore, 1986). Despite the fact that the theoretical and empirical basis of such claims remains in serious doubt, many OECD countries, including New Zealand, have in recent years embarked on reform programmes designed to "free-up" the labour market.

The nature of these reforms has differed from country to country depending on the existing institutional and regulatory framework, legal traditions, the political and industrial strength of the union movement, the perceived magnitude of the economic crisis and the ideological sympathies of the party in power. For example, the changes to labour market regulation in Britain and New Zealand have been substantial. By contrast, only minor policy adjustments have occurred in countries with a strong corporatist tradition. Generally speaking, attempts at increasing labour market flexibility have focussed on two kinds of changes.

First, there have been various measures introduced throughout the OECD to enhance labour flexibility (i.e. the quality, adaptability and mobility of the workforce). These have included:

i) policies to improve post-compulsory education and the range of training (and retraining) programmes;

ii) work-study programmes designed to ease the transition from school to work;

iii) remedial programmes to improve basic numeracy and literacy, and enhance work attitudes and habits;

iv) job transition training for workers displaced by plant closures;

v) improvements in placement services and vocational counselling;

vi) mobility allowances and relocation assistance for people needing to move from one region to another to find suitable work;

vii) more flexible public housing policies to facilitate geographical mobility; and

viii) changes to occupational licensing to reduce the existing barriers to entry (Casey and Bruche, 1985).

Second, there have been a series of policy initiatives in certain OECD countries to increase the flexibility (downwards) of real wages and non-wage labour costs. These have included:

i) measures to reduce union bargaining rights and union coverage;

ii) policies to encourage the decentralisation of wage bargaining in both the public and private sectors;

iii) measures to enhance competition in labour and product markets, in particular the deregulation of highly unionized industries;

iv) reductions in mandatory non-wage labour benefits; 
v) the removal of certain constraints on hiring and firing, in particular the weakening of job security provisions;

vi) the failure to adjust the statutory minimum wage in line with changes in the CPI and/or the abandonment of solidaristic wage policies;

vii) modifications to youth rates to facilitate greater downward wage flexibility;

viii) cuts in unemployment benefits and more restrictive eligibility criteria; and

ix) policies to encourage more flexible work practices (i.e. with respect to hours, shiftwork, part-time employment, temporary work and limited-duration contracts).

Quite apart from governmental measures of this nature, many employers have exploited the opportunities provided by the economic recession of the $1980 \mathrm{~s}$ and the unions' weaker bargaining position to restore certain managerial prerogatives which had been lost during the 1960 s and 1970 s and to increase their control over the workplace (e.g. with respect to manning levels, payment systems, hours of work, rostering, shift work, the deployment of labour within the enterprise, the introduction of new technology etc) (see Crouch, 1986). In addition, employers in a large number of OECD countries have taken an active interest in Japanese models of personnel management and industrial relations and have sought where possible to adopt Japanese practices (e.g. the creation of company unions, company loyalties, employee participation in low-level decision making, flexible work groups etc).

The position of organised labour has been further weakened by the changing structure of employment within advanced industrialised democracies: the diminishing importance of industries with a high level of unionisation, the growth of the service sector, the rise in part-time work, temporary work and self-employment, and the general decline in the size of individual enterprises and work-places (see Brown, 1986). The impact of all these structural, managerial and policy changes has been to place the union movement in a much weaker and more vulnerable position than was the case during the 1960s and 1970s. The pattern internationally, of course, is very uneven. For the most part, the union movements in the Nordic countries and Austria, and to a lesser extent the Low countries, France, Italy and West Germany, have remained relatively unscathed. Against this, the trade unions have been more severely affected in Britain and North America. In the United States, for example, union coverage has fallen significantly in recent years, collective bargaining continues to decline in importance, many unions have been forced into concession bargaining (especially during the early 1980s) and the extent of pattern bargaining appears to have diminished (Cullen, 1985; Edwards and Podgursky, 1986).

Likewise in Britain the union movement has suffered some notable setbacks under the Thatcher Government (Brown, 1986; McBride, 1986; Soskice, 1984). Union membership fell by almost 2 million between 1980 and 1984, largely as a result of the disproportionate number of highly unionised manufacturing plants which closed during this period (Kelly, 1987, p.275). A gradualist programme of industrial relations law reform - the Employment Act (1980), the Employment Act (1982), and the Trade Union Act (1984) - has challenged some of the main foundations of trade union power (Gregory, 1985). For example, civil immunities have been withdrawn from many trade union activities, including political, sympathy and inter-union strikes, secondary picketing and all strikes which have not been endorsed by a secret ballot. The sanctioning of closed shops requires regular ballots and an 85 percent majority in favour. Procedures for establishing trade union recognition and enforcing industry collective agreements on nonunion firms have been abolished. Clauses in subcontracts which require only the employment of union labour have been prohibited. In addition, wage councils (which set legal minimum wages in various industries) have been abolished, as has the Fair Wages Resolution requiring firms supplying government services to pay fair wages. Finally, there have been important changes to public sector pay-fixing arrangements and the Government has won some notable victories in its disputes with public sector employees, above all against the miners in 1985 . 
Despite these legislative impediments and the hostile political and economic environment, the union movement has proved to be remarkably resilient. According to recent evidence which has come to light, for example, over two-thirds of British workers remain covered by collective bargaining arrangements, the overall number of shop stewards actually increased between 1980 and 1984, and there has been no major change during the $1980 \mathrm{~s}$ in the incidence of joint shop steward committees and interestablishment combine committees (Kelly, 1987, pp.275-276). On the other hand, there has been a substantial decline in the proportion of establishments with closed shop arrangements and the number of workers covered by them, and of course the political influence of organised labour has declined massively. From being major actors in the corridors of power in the 1970 s, union leaders are now almost completely excluded from the policy-making process.

It is unlikely that union movements in other OECD countries will be faced in the immediate future with such a concerted and determined attack on their rights and power base as has occurred during the Thatcher years in Britain. Nevertheless, the New Right is now influential in many western countries, including Australia and New Zealand (Dabscheck, 1987). Hence, irrespective of the political complexion of the government in power, there are likely to be continuing pressures for labour market deregulation. In New Zealand debate will probably centre on the provisions in the Labour Relations Act relating to minimum union size, union membership, contestability, and national awards. But it is also likely that there will be pressures to undermine job security provisions, health and safety provisions and income security arrangements (i.e. unemployment benefits, sickness benefits, accident compensation etc). Doubtless, too, any government moves to require greater worker participation and industrial democracy will be vigorously resisted.

\section{The Calmfors-Dirffill thesis and the merits of decentralised wage bargaining}

As noted in the previous section, the 1980 s have witnessed a general trend towards the decentralisation of wage bargaining within the OECD, encouraged for the most part by government policy. The rationale behind this move rests on the assumption that decentralised bargaining will enhance the efficiency of the labour market and increase wage flexibility (i.e. both in terms of real and relative wages). This in turn, it is argued, will improve economic performance with lower unemployment and faster productivity growth. Whether such an analysis is correct remains highly contentious. It is by no means certain whether decentralised bargaining at the plant or enterprise level is either a necessary or sufficient condition for wage flexibility; nor is it clear whether a high degree of wage flexibility is a necessary or sufficient condition for achieving desirable macroeconomic outcomes.

An analysis by Grubb, Jackman and Layard (1983) indicates that countries with relatively decentralised bargaining arrangements have markedly different levels of wage flexibility. In Japan and Switzerland both real and nominal wages are relatively flexible whereas in the United Kingdom there is a substantial degree of real wage rigidity and in the United States a high degree of nominal wage rigidity. By contrast, a number of countries with relatively centralised bargaining arrangements, such as Austria, Finland, Sweden and the Netherlands, exhibit a substantial degree of nominal and real wage flexibility. Interestingly, New Zealand is among those countries which, according to Grubb, Jackman and Layard, have a significant degree of wage flexibility; yet its economic performance for the past few decades has been relatively poor.

Over the years there have been many attempts to assess the relative efficiency of different pay-fixing systems and explore the relationship between the degree of bargaining centralisation (or coordination) and economic performance (as measured by a range of indicators) (for instance Bruno and Sachs, 1985; Calmfors and Driffill, 1987; Castles, 
1987; Crouch, 1985; McCallum, 1983; Schmitter, 1981; and Tarantelli, 1983). In general, such studies indicate that the performance of OECD countries with corporatist industrial relations systems (i.e. a high level of centralisation and coordination) has been superior to those with liberal systems (i.e. decentralised bargaining and very limited central coordination). Crouch (1985) shows, for example, that on the basis of a study of 19 OECD countries, corporatist systems performed better with respect to industrial conflict (1965-80), inflation (mid-1960s to mid-1970s), peak inflation rates during the mid 1970 s and the misery index (i.e. the sum of the rates of inflation and unemployment).

Broadly similar results were obtained by Castles (1987). For example, according to Castles, unemployment as measured in three separate periods (1960-73, 1974-79, and 1980-84) was consistently lower in countries with corporatist systems (see Table 1). Castles's results also showed a negative association between corporatist arrangements and inflation, at least during the period 1974-79, and a positive relationship between corporatism and total government outlays. On the other hand, the rate of economic growth does not seem to be related to a country's industrial relations system.

Table 2 provides an overview of economic developments in 18 OECD countries using two measures: the misery index and the happiness index. It should be noted that the misery index is normally generated by adding the absolute values of unemployment and inflation while the happiness index is calculated on the basis of employment and social wage indicators. However, in this instance the indexes in Table 2 have been compiled from the rank orders in Table 1; the appropriate rank orders have been added and then reranked (Castles, 1987, p.389). Again the results show corporatist industrial relations systems in a favourable light: there is a negative association between corporatism and the misery index and a positive relationship between corporatism and the happiness index. Indeed, only in those countries with centralised wage bargaining arrangements, such as Austria, Norway and Sweden, were the main objectives of the union movement - in terms of relatively full employment and high social wage levels - achieved on a consistent basis. By contrast, among the countries which obtained a low ranking on the happiness index were Britain, Canada, and the United States, all three with decentralised bargaining systems. Note, too, that New Zealand's relative performance, as revealed in Tables 1 and 2 , has been reasonably mediocre and on the whole has deteriorated since the mid-1970s. Only with respect to employment (1960-79) and economic growth (1980-84) has New Zealand ranked near the top of the international league.

Such analyses are, of course, open to numerous objections. The desirability of high levels of government expenditure is strongly challenged in many quarters. The relative importance of price stability and full employment remains in dispute. And all analyses of this nature are crucially dependent on the criteria used to measure the degree of centralisation and the categories into which particular countries are put. As Table 3 shows, various scholars using different criteria have in recent years produced some strikingly different results, at least with respect to particular countries (e.g. Belgium, Germany, the Netherlands and Switzerland).

Quite apart from this, the suggestion that centralised bargaining arrangements are generally preferable to decentralised ones continues to be strongly contested by many economists. As already noted, it is argued that the best performing economies in recent years, most notably Japan and Switzerland, have decentralised industrial relations systems, and that one of the highest employment growth rates during the past few decades has occurred in the United States, also a country with decentralised bargaining. Is there any way of reconciling such views with the claims that corporatist solutions are best? After all, on theoretical grounds both sides appear to have a strong case. Decentralised bargaining, arguably, enables wages to reflect more accurately changes in productivity and market conditions at the enterprise level. Likewise, centralised bargaining by large encompassing organizations provides the opportunity for wages to be adjusted in response to economy-wide developments and external shocks, and also encourages the bargaining 
Table 1: Rank orders of inflation, unemployment, economic growth and total government outlays in 18 countries in the periods $1960-73$, 1974-79 and 1980-84

\begin{tabular}{|c|c|c|c|c|c|c|c|c|c|c|c|c|}
\hline \multirow[t]{2}{*}{ Countries: } & \multicolumn{3}{|c|}{ Inflation $^{1}$} & \multicolumn{3}{|c|}{ Unemployment $^{2}$} & \multicolumn{3}{|c|}{ Economic Growth ${ }^{3}$} & \multicolumn{3}{|c|}{ Government Outlays ${ }^{4}$} \\
\hline & $1960-73$ & $1974-79$ & $1980-84$ & $1960-73$ & $1974-79$ & $1980-84$ & $1960-73$ & $1974-79$ & $1980-84$ & $1960-73$ & $1974-79$ & $1980-84$ \\
\hline Australia & 4 & 12 & 9 & 10 & 12 & 9 & 14 & 16 & 8 & 14 & 16 & 16 \\
\hline Austria & 6 & 3 & 5 & 7 & 3 & 5 & 6 & 2 & 5 & 3 & 6 & 9 \\
\hline Belgium & 4 & 5 & 6 & 14 & 13 & 17 & 3 & 9 & 10 & 9 & 7 & 4 \\
\hline Canada & 1 & 8 & 8 & 16 & 17 & 14 & 7 & 7 & 15 & 13 & 12 & 12 \\
\hline Denmark & 17 & 14 & 10 & 5 & 14 & 12 & 9 & 12 & 6 & 10 & 4 & 3 \\
\hline Finland & 15 & 13 & 12 & 13 & 9 & 7 & 2 & 9 & 2 & 15 & 14 & 13 \\
\hline France & 8 & 11 & 15 & 7 & 10 & 10 & 3 & 4 & 15 & 4 & 10 & 8 \\
\hline Germany & 3 & 2 & 3 & 3 & 7 & 8 & 11 & 5 & 10 & 5 & 5 & 10 \\
\hline Ireland & 16 & 16 & 17 & 17 & 18 & 18 & 8 & 2 & 9 & 8 & 8 & 5 \\
\hline Italy & 10 & 18 & 18 & 17 & 15 & 14 & 3 & 7 & 10 & 11 & 11 & 6 \\
\hline Japan & 18 & 10 & 1 & 5 & 5 & 1 & 1 & 5 & 1 & 18 & 18 & 17 \\
\hline Netherlands & 11 & 4 & 4 & 4 & 11 & 16 & 9 & 11 & 18 & 1 & 1 & 2 \\
\hline New Zealand5 & 12 & 15 & 16 & 1 & 2 & 6 & 18 & 18 & 4 & 12 & 13 & 14 \\
\hline Norway & 13 & 7 & 13 & 7 & 4 & 3 & 11 & 1 & 4 & 7 & 3 & 7 \\
\hline Sweden & 8 & 9 & 14 & 10 & 5 & 4 & 13 & 14 & 6 & 2 & 2 & 1 \\
\hline Switzerland & 6 & 1 & 2 & 1 & 1 & 1 & 15 & 17 & 10 & 17 & 17 & 18 \\
\hline United Kingdom & 14 & 17 & 11 & 10 & 8 & 12 & 17 & 14 & 17 & 6 & 9 & 11 \\
\hline United States & 1 & 6 & 6 & 15 & 16 & 11 & 16 & 12 & 14 & 16 & 15 & 15 \\
\hline
\end{tabular}

Notes: The rankings are based on assumed union preferences. This means that low unemployment and inflation score highly (ie low numbers) as do high growth and government outlays.

1. Average annual year-to-year percentage change in consumer price index.

2. Average annual unemployment as a percentage of the total labour force.

3. Average annual year-to-year percentage change in real GDP per capita.

4. Average annual total outlays of government as a percentage of GDP.

5. Government expenditure in New Zealand from House of Representatives, Public Accounts.

Source: Francis Castles (1987) p. 384. 
Table 2: Rank orders for misery and happiness indexes 1960-73, 1974-79, 1980-84.

Countries Misery Index

Happiness Index

$\overline{1960-73 \quad 1974-79 \quad 1980-84}$

$\overline{1960-73 \quad 1974-79 \quad 1980-84}$

\begin{tabular}{lllllll}
\hline Australia & 5 & 13 & 7 & 13 & 16 & 16 \\
Austria & 3 & 2 & 3 & 3 & 3 & 3 \\
Belgium & 10 & 9 & 14 & 11 & 10 & 13 \\
Canada & 9 & 14 & 11 & 17 & 17 & 17 \\
Denmark & 13 & 16 & 11 & 8 & 8 & 4 \\
Finland & 17 & 10 & 9 & 15 & 13 & 10 \\
France & 6 & 11 & 15 & 4 & 10 & 5 \\
Germany & 1 & 3 & 4 & 2 & 4 & 5 \\
Ireland & 18 & 18 & 18 & 14 & 14 & 14 \\
Italy & 16 & 17 & 17 & 15 & 14 & 10 \\
Japan & 14 & 6 & 1 & 11 & 12 & 5 \\
Netherlands & 6 & 6 & 10 & 1 & 4 & 5 \\
New Zealand & 3 & 8 & 11 & 6 & 6 & 10 \\
Norway & 12 & 4 & 5 & 7 & 1 & 2 \\
Sweden & 10 & 5 & 7 & 5 & 1 & 1 \\
Switzerland & 2 & 1 & 2 & 10 & 8 & 9 \\
United Kingdom & 15 & 14 & 16 & 9 & 7 & 14 \\
United States & 8 & 12 & 6 & 18 & 18 & 17 \\
& & & & & &
\end{tabular}

Rank order correlation with neocorporatism

Correlations are Spearman's Rho. ${ }^{*}=$ significance at .05 level; $* *=$ significance at .01 level.

The misery index generally measures the combined rates of inflation and unemployment, while the happiness index measures the extent of full employment together with the extent of total government outlays. The indexes in the above table, however, have been constructed by adding the appropriate rank orders in Table 1 and then reranking.

Source: Francis Castles (1987) p.389. 
Table 3: Rank orderings of countries according to the degree of centralisation

\begin{tabular}{lllll} 
Calmfors \& Driffill & Schmitter & Cameron & Blyth & Bruno-Sachs \\
\hline 1.Austria & 1.Austria & 1.Sweden & 1.Austria & 1.Austria \\
2.Norway & 2.Norway & 2.Norway & 2.Norway & 2.Germany \\
3.Sweden & Sweden & 3.Austria & 3.Sweden & 3.Netherlands \\
4.Denmark & 4.Denmark & 4.Belgium & 4.Denmark & 4.Norway \\
5.Finland & Finland & 5.Finland & 5.Finland & Sweden \\
6.Germany & 6.Netherlands & 6.Denmark & 6.New Zealand & 6.Switzerland \\
7.Netherlands & 7.Belgium & 7.Netherlands & 7.Australia & 7.Denmark \\
8.Belgium & 8.Germany & 8.Germany & 8.Germany & 8.Finland \\
9.New Zealand & 9.Switzerland & 9.Britain & 9.Belgium & 9.Belgium \\
10.Australia & 10.US & 10.Australia & 10.Netherlands & 10.Japan \\
11.France & 11.Canada & 11.Switzerland & 11.Japan & 11.New Zealand \\
12.Britain & 12.France & 12.Italy & 12.France & 12.Britain \\
13.Italy & 13.Canada & 13.Canada & 13.Britain & 13.France \\
14.Japan & 14.Italy & 14.US & 14.Italy & 14.Italy \\
15.Switzerland & & 15.France & 15.US & 15.Australia \\
16.US & & 16.Japan & 16.Canada & 16.Canada \\
17.Canada & & & & 17.US \\
& & & &
\end{tabular}

Source: Calmfors and Driffill (1987) p.46.

parties to consider a wider range of interests during the course of their negotiations. In short, it facilitates the internalization of the externalities associated with wage increases.

A recent contribution to the debate by Calmfors and Driffill (1987) offers a possible solution to this conundrum. In a fascinating paper, these economists argue that there are two desirable types of bargaining arrangements (i.e. from the perspective of achieving real wage restraint and positive macroeconomic outcomes): either a heavily centralised system or a highly decentralised system. Bargaining systems which fall somewhere between these models are, in general, economically inferior. What this means, in other words, is that there is a hump-shaped relationship between real wages (and unemployment) and the degree of centralisation, rather than a monotonic relationship whereby increased centralisation reduces real wages (see Figure 1). As Calmfors and Driffill (p.2) note, such a hypothesis is consistent with Olson's (1982) contention that organised interests are the most damaging and disruptive economically when they are not sufficiently encompassing 
to bear a substantial portion of the external costs of their behaviour and yet are powerful enough to alter economic outcomes.

Calmfors and Driffill take as their definition of centralisation "the extent of inter-union and inter-employer cooperation in wage bargaining with the other side" (p.5), or more particularly the "extent of coordination both within and between various central organisations" (p.6). Hence, they reject definitions based on the level at which wagefixing occurs, the degree of associational monopoly and unity enjoyed by the central union and employer organisations, and the negotiating rights and powers vested with the peak organisations (Visser, 1983). On the basis of their definition they seek to rank 17 OECD countries (using an ordinal rather than a cardinal scale). As Table 3 shows, they rank Austria, Norway and Sweden as having the most centralised bargaining systems and Switzerland, the United States and Canada as having the least centralised. Belgium, New Zealand and Australia have the rather dubious distinction of being ranked in the intermediate position.

Figure 1: The hump-shape hypothesis

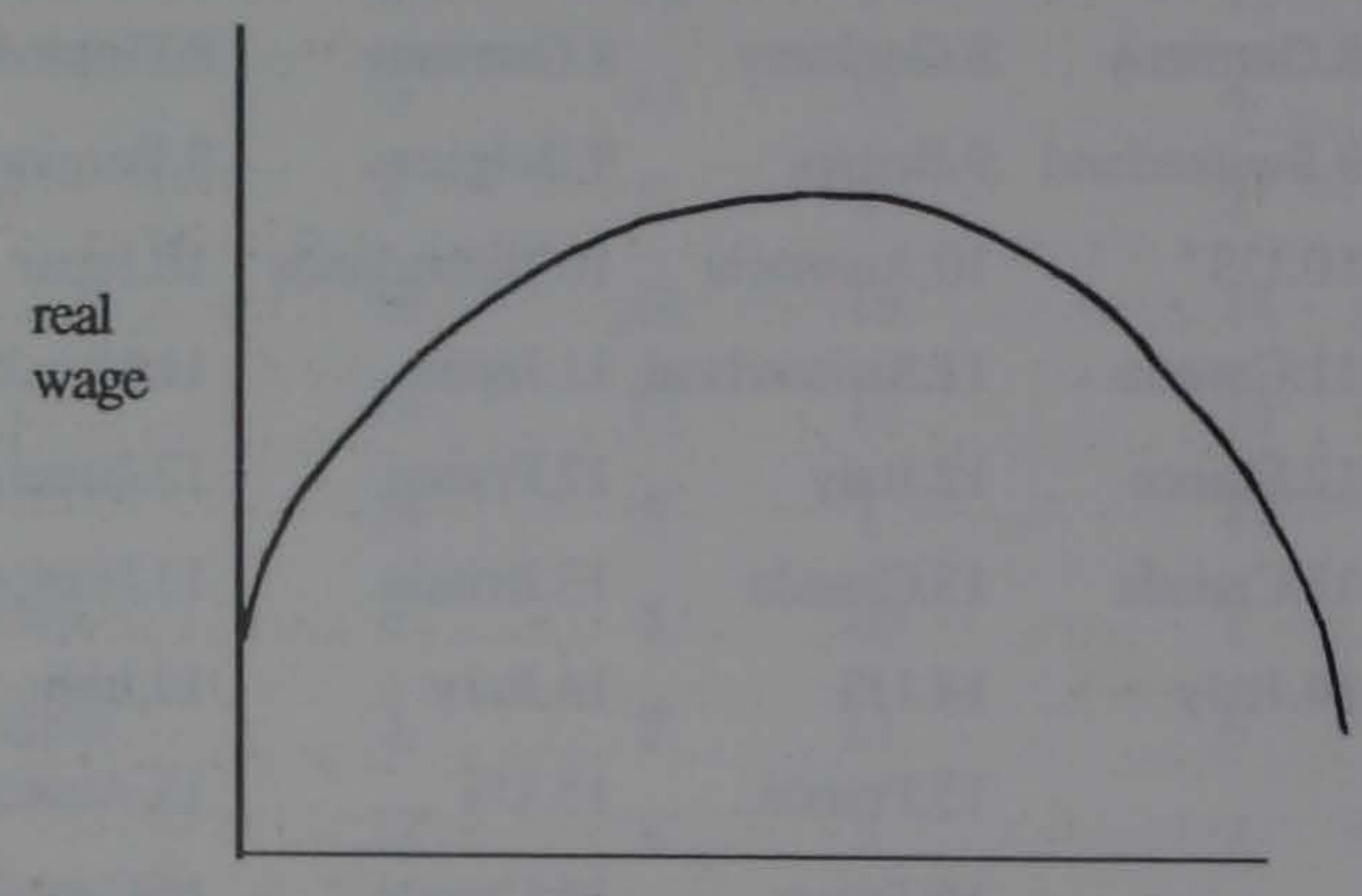

centralisation

Having ranked these 17 countries and grouped them into 3 categories - centralised, intermediate and decentralised - Calmfors and Driffill evaluated the relative macroeconomic performance of the 3 groups during 2 time periods, 1963-73 and 1974-85. Eight performance indicators were used including unemployment, the change in unemployment, the employment population, the change in the employment population, the Okun "misery index", and so forth (pp.47A-47B). The results of this analysis (together with various other tests) strongly supported their hump-shape hypothesis: the best performances were achieved by the most centralised and decentralised economies, the worst by the intermediate group. Interestingly, the hump-shaped relation was most striking with regard to the changes in employment performance between the periods before and after the first oil shock. At the same time, no evidence was found to support the proposition that there is a monotonic relationship between the degree of centralisation and macroeconomic performance.

Calmfors and Driffill seek to explore why it is that other researchers have found strong evidence of a monotonic relation between centralisation (or corporatism) and economic outcomes (especially the degree of real-wage moderation). Their conclusion, in brief, is that the classification systems which have been adopted have been flawed and that certain countries, most notably Japan and Switzerland, have sometimes been placed in the wrong 
category. In addition, the results have been affected by the particular time periods chosen (see pp.14-20).

Calmfors and Driffill are well aware that their own analysis is open to question, and that the theoretical framework which they develop to account for their results is incomplete (pp.20-38). For example, they acknowledge that their analysis focuses primarily on the relation between centralisation and the aggregate real wage and that they fail to give sufficient attention to the flexibility of relative wages in different industrial relations systems. But there are other problems as well.

First, their ranking of certain countries is puzzling. It seems rather doubtful whether, according to their definition of centralisation, Australia should be ranked lower than New Zealand. Indeed, it is arguable that during the period of indexation (1974-81) and the Wage Accord Marks I and II (1983-87) Australia exhibited a high degree of centralisation, comparable perhaps to that prevailing in Austria and Norway. Similarly, it is uncertain why Britain, which according to Crouch has the "most decentralised union movement in the industrial world" (1985, p.128), is located ahead of five other countries (see Table 3).

Second, and related to this, Calmfors and Driffill appear to have ignored the crucial role which incomes policies have played in a great many OECD countries during the past few decades. In the case of New Zealand, incomes policies of one kind or another were in force for most of the period between 1971 and 1984. Does this not imply a high level of centralisation or coordination?

Third, little consideration is given to the reasons for the variable economic performance of countries within the three categories identified. For instance, economic outcomes in the countries grouped within the decentralised category (France, Britain, Italy, Japan, Switzerland, the United States and Canada) have varied significantly in the past decade or so, the British experience being markedly worse than that of Switzerland and Japan. Are these variable outcomes related to their different labour market institutions or to other factors?

Fourth, it appears that in assessing the degree of bargaining centralisation, Calmfors and Driffill have concentrated primarily on pay fixing arrangements in the private sector. But this is unsatisfactory. Most OECD countries have a large public sector, and bargaining outcomes in this sector often have a significant impact on trends in the private sector. Moreover, pay fixing arrangements in the public sector are generally more centralised than in the private sector. Certainly this has been the case in New Zealand where for many years most public servants have received uniform annual general adjustments in their pay rates. Although such arrangements are in the process of radical change, the degree of bargaining centralisation in the public sector up to now raises further questions about the accuracy of placing New Zealand in the intermediate category.

Finally, just as highly decentralised and fragmented bargaining is neither a necessary nor a sufficient condition for ensuring desirable macroeconomic outcomes, much the same can be said for centralised bargaining. The experience of Denmark, for example, has differed substantially from that of Austria and Norway. The central point, then, is that institutional arrangements must not be looked at in isolation. It is also necessary to consider a host of socio-political variables. Hence, decentralised bargaining may yield favourable economic results when the union movement is weak, union density low, worker deference high, conflict over income shares limited and so forth. By contrast, if the union movement is powerful, if union density is high, if there are strongly held notions of comparative wage justice and vigorous collectivist traditions, and if employees show little deference and readily partake in strike action, then decentralised bargaining may yield very disappointing results. But so might a centralised system.

What implications does this discussion have for New Zealand? If the Calmfors Driffill hypothesis is valid, and if New Zealand is indeed uncomfortably located in the intermediate category towards the top of the hump, then clearly this means that, other things being equal, the country's long-term economic performance is likely to be inferior to those OECD countries with highly centralised or highly decentralised industrial 
relations systems. And this implies that it would be to New Zealand's advantage either to press ahead with attempts to decentralise wage bargaining to the plant or company level or alternatively introduce a centralised, coordinated system along Austrian or Scandinavian lines. Note too that if Calmfors and Driffill are correct, tinkering, fine tuning or marginal changes in one direction or another will not be enough; only radical surgery can be expected to bring major economic gains (pp.39-40).

The question, of course, is which direction would be best? Easton $(1986,1988)$ argues that New Zealand should adopt a more centralised approach. He maintains that this would be consistent with New Zealanders' preference for social cooperation and that such a system is likely to be superior to a highly decentralised model in a small, open economy (1988, p.78). But he recognizes that there are problems in moving in such a direction. For one thing, both the Business Roundtable and the Employers Federation continue to press for substantial deregulation of the labour market and the removal of various union rights and privileges. The Business Roundtable, for example, is strongly opposed to compulsory unionism (in any form), it rejects the concept of national awards, and it sees no justification in the retention of the Labour Court and the Arbitration Commission. Under the proposals bargaining would occur mainly at the plant or enterprise level and the union structures would be radically altered. The Employers Federation, partly because of its broader constituency, is more pragmatic in its approach and is prepared to tolerate the continuation of the award system and a separate jurisdictional arrangement for labour relations. Nevertheless, it favours voluntary unionism and an end to the requirement for unions to have a minimum of 1000 members. It also advocates greater bargaining decentralisation, but sees merit in bargaining at the industry, rather than the plant, level in some instances. Hence, neither the Business Roundtable nor the Employers Federation would support any move to a greater degree of centralisation in wage-fixing.

The position of the union movement, on the other hand, is less clear. Some unions favour centralised bargaining, partly as a means of increasing the political influence of the union movement and partly because of the risks associated with major changes in bargaining structures. Other unions, however, believe that political and economic circumstances are such that there is no option but to move to more decentralised bargaining arrangements and that the union movement should exploit the current opportunities to restructure and gear itself so that it can be effective in the new environment. Given this division of opinion, it seems most unlikely that the Council of Trade Unions would be willing and able to give strong support to Easton's proposals.

Irrespective of this, there are many practical difficulties associated with the centralisation option. What kind of institutional arrangements would be best - the Austrian, Norwegian or Australian model? What enforcement mechanisms would be required? How would the Employers Federation and the Council of Trade Unions be strengthened, and what powers would they be given with respect to claim formulation, negotiating rights, the calling of strikes and lockouts and so forth? In view of all these problems I do not believe that a significant shift in the direction of greater centralisation is feasible (Boston, 1986, pp.9-11).

This appears to leave only one option, namely to decentralise the process of wagefixing as much as possible. But this option also presents difficulties. Bringing about changes in the pattern of industrial relations is not easy, as recent developments both in New Zealand and elsewhere testify. Moreover, I am sceptical as to whether a radical decentralisation of wage bargaining in New Zealand would necessarily yield significant macroeconomic gains. It is not satisfactory simply to point to the favourable performance of certain economies with decentralised pay fixing like Japan, Switzerland and the United States. Each of these countries is very different from New Zealand in terms of legal traditions, political history, union density and organisation, cultural norms and economic structure. More relevant for comparative purposes are Britain and Ireland; but neither of these economies have much to commend them, apart perhaps from the good GDP growth experienced by Britain in recent years. 
Now it might be objected that New Zealand's performance could be greatly improved if a move to decentralised bargaining was combined with a general assault on union rights, worker protection, income security provisions, and so forth. This, in short, is the strategy of the New Right. The aim here would be to minimise the role of the state in the economy, strengthen the managerial prerogatives of employers, reduce the political influence of the union movement, and dramatically lower union coverage. I do not know what the economic consequences of such a strategy would be. It is certainly possible that it would result in faster productivity growth, greater real-wage flexibility and higher employment growth. But it would be at a significant cost in terms of social rights and distributive justice. Consequently, I do not favour such an approach.

Where does this leave us then? As in most areas of public policy it leaves us seeking better empirical data, deeper analysis and, for the most part, muddling through as best we can. It also leaves us hoping that the Calmfors-Driffill thesis is wrong, or at least that New Zealand does not, after all, occupy such an unfavourable position on their centralisation scale.

\section{Conclusion}

The main points of this paper can be summarised very simply. First, there has been a general change in the pattern of macroeconomic management within the OECD during the past decade. This has seen greater emphasis placed on restrictive monetary and fiscal policies and a corresponding decline in direct state intervention in the wage-fixing process. Nevertheless, corporatist incomes policies are still a central feature of macroeconomic policy in Scandinavia and Austria, and statutory incomes policies continue to be used from time to time by governments in many OECD countries. Second, there has been a widespread trend towards the decentralisation of wage bargaining during the 1980s with many governments, including those in Britain, France, New Zealand and more recently Australia, making policy changes to facilitate this process. More broadly, there has been a quest within much of the OECD for labour market reform and greater wage flexibility. Third, there is a continuing debate concerning the relative merits of different wage-fixing systems. Within this context the recent contribution by Calmfors and Driffill provides plenty of food for thought. Finally, despite the easing of inflationary pressures since the early 1980 s and the recent fall in unemployment in many OECD countries, questions relating to the operation of the labour market and the appropriate role of the state in the regulation of employment and industrial relations seem destined to remain high on the political agenda. This will certainly be the case in New Zealand where the Business Roundtable appears unwilling to settle for anything less than a radical reshaping of the entire social and political order.

\section{References}

Addison, J (1979) Wage policies and collective bargaining developments in Finland, Ireland and Norway Paris, OECD.

Boston, J (1984) Incomes policy in New Zealand, 1968-1984 Wellington, Victoria University Press for the Institute of Policy Studies.

Boston, J (1985) Incomes policy and the 1985-1986 wage round: from non-market failure to market failure? New Zealand journal of industrial relations 10: 65-82.

Boston, J (1986) Is corporatism a viable model for New Zealand? New Zealand journal of business 8: 1-13. 
Brown, W (1986) The changing role of trade unions in the management of labour British journal of industrial relations 24: 161-188.

Bruno, M and Sachs, J (1985) Economics of worldwide stagflation Cambridge Mass., Harvard University Press.

Buiter, W H and Miller, M H (1983) Changing the rules: economic consequences of the Thatcher regime Brookings papers on economic activity 2: 305-365.

Burch, M (1985) Coping with stagflation: some policy lessons from Australia The political quarterly 56: 409-418.

Calmfors, L and Driffill, J (1987) Centralisation of wage bargaining and macroeconomic performance. Unpublished paper, Institute for International Economic Studies, University of Stockholm.

Casey, B and Bruche G (1985) Active labour market policies: an international overview Industrial relations 24: 37-61.

Castles, F (1987) Neocorporatism and the 'happiness index', or what the trade unions get for their cooperation European journal of political research 15: 381-393.

Crouch, C (1977) Class conflict and the industrial relations crisis London, Humanities Press.

Crouch, C (1985) Conditions for trade union wage restraint. In Lindberg, L N and C S Maier (eds) The politics of inflation and economic stagnation Washington DC, The Brookings Institution.

Crouch, C (1986) The future prospects for trade unions in Western Europe The political quarterly 57: 5-17.

Cullen, P (1985) Recent trends in collective bargaining in the United States International labour review 124: 299-322.

Dabscheck, B (1987) New right or old wrong? Ideology and industrial relations Journal of industrial relations 29: 425-449.

Duda, H and Todtling, F (1986) Austrian trade unions in the economic crisis. In Edwards, $\mathrm{R}$ et al (eds) Unions in crisis and beyond: perspectives from six countries London, Auburn House.

Dunkley, G (1984) Can Australia learn from Austria about incomes policies? Journal of industrial relations 26: 365-384.

Easton, B (1986) Wages and the poor Wellington, Allen and Unwin.

Easton, B (1988) Fixing a rate for the job The listener 7 May: 78.

Edwards, R and Podgursky, M (1986) The unraveling accord: American unions in crisis. In Edwards, $\mathrm{R}$ et al (eds) Unions in crisis and beyond: perspectives from six countries London, Auburn House. 
Flanagan, R, Soskice, D and Ulman, L (1983) Unionism, stabilization and incomes policy Washington DC, The Brookings Institution.

Gerritsen, R (1986) The necessity of "corporatism": the case of the Hawke labour government Politics 21: 45-54.

Gregory, R (1985) Industrial relations, the law and government strategy Political quarterly 56: $23-32$.

Grubb, P, Jackman, R and Layard, R (1983) Wage rigidity and unemployment in OECD countries European economic review 22: 11-39.

Gylfason, T and Lindbeck, A (1982) The political economy of cost inflation Kyklos 35: 430-455.

Hudson, M (1980) 'Concerted action': wages policy in West Germany, 1967-1977 Industrial relations journal 11: 5-16.

Kelly, J (1987) Trade unions through the recession 1980-1984 British journal of industrial relations 25: $275-282$.

Lash, S (1985) The end of corporatism? The breakdown of centralised bargaining in Sweden British journal of industrial relations 23: 215-239.

Marin, B (1985) Austria - The paradigm case of liberal corporatism? In Grant, W (ed) The political economy of corporatism London, Macmillan.

Marks, G (1986) Neocorporatism and incomes policy in Western Europe and North America Comparative politics 18: 253-277.

McBride, S (1986) Mrs Thatcher and the post war consensus: the case of trade union policy Parliamentary affairs 39: 330-340.

McCallum, J (1983) Inflation and social consensus in the 1970s The economic journal 93: $784-805$.

Mire, J (1981) Industrial relations in Austria New Zealand journal of industrial relations 6: $139-149$.

Moss, B (1987) After the Auroux laws: employers, industrial relations and the right in France. Paper prepared for the annual conference of the Australasian Political Studies Association, Auckland, New Zealand.

Mulvey, C (1984) Wage policy and wage determination in 1983 Journal of industrial relations 26: 112-119.

OECD (1984) Economic Surveys: Australia Paris: OECD.

OECD (1985) Economic Surveys: Norway Paris, OECD.

OECD (1986) Economic Surveys: Denmark Paris, OECD.

Olson, M (1982) The Rise and decline of nations New Haven, Yale University Press. 
Parri, L (1983) Switzerland: A fair and tidy case of neo-corporatism European University Institute 151/83 (SSCP 11).

Petridis, A (1986) Wages policy and wage determination in 1985 Journal of industrial relations 28: 124-132.

Petridis, A (1987) Wage policy and wage determination in 1986 Journal of industrial relations 29: 75-83.

Piore, M (1986) Perspectives on labour market flexibility Industrial relations 25: 146166.

Plowman, D (1982) Indexation and beyond: Australian wage determination 1978-1982 New Zealand journal of industrial relations 7: 189-204.

Prager, J (1981) Austria's "social partnership" - a view from within Policy studies 1:145156.

Schmitter, P and Lehmbruch, G (eds) (1979) Trends towards corporatist intermediation London, Sage.

Schmitter, P C (1981) Interest intermediation and regime governability in contemporary Western Europe and North America. In Berger, S D (ed) Organizing interests in Western Europe Cambridge University Press.

Schwerin, D (1980) The limits of organization as a reponse to wage-price problems. In Rose, R (ed) Challenge to governance London, Sage.

Singleton, G (1985) The Economic Planning Advisory Council: The reality of consensus Politics 20: 12-25.

Soskice, D (1984) Industrial relations and the British economy 1979-1983 Industrial relations 23 : 306-323.

Standing, G (1986) Meshing labour flexibility with security: an answer to British unemployment? International labour review 125: 87-106.

Stewart, R (1985) The politics of the Accord: does corporatism explain it? Politics 20: 26-35.

Tarantelli, E (1983) The regulation of inflation in western countries and the degree of neocorporatism European University Institute, 154/83 (SSCP 14).

Towers, B (1987) Managing labour flexibility Industrial relations journal 18: 79-83.

Van Ginneken, W (1987) Wage policies in industrialised market economies from 1971 to 1986 International labour review 126: 379-403.

Visser, J (1983) The unification and centralisation of the trade union movement: a comparison of ten countries European University Institute 163/83 (SSCP 23). 